\title{
The World System in the Information Age: Structure, Processes, And Technologies
}

\author{
Joachim K. Rennstich
}

Summary: The new information age has the potential to not only alter the historical path of world system development as other socio-technological paradigmatic shifts have done, but to transform it substantially. One school of thought argues for a complete upending of past patterns with nation states in their hierarchical alignment as the center core and periphery of power in this system (Wallerstein, 1999; Chase-Dunn \& Inoue, 2010). An alternative view instead argues that the regularized interaction that characterizes a world system may envisage a number of modes of production without altering its fundamental structure (Denemark, Friedman, Gills \& Modelski, 2000; Thompson, 2000). The world system in this view is made up of a variety of complex intraorganizational and interorganizational networks intersecting with geographical networks structured particularly around linked clusters of socioeconomic activity. Information and carrier technologies based on new forms of information technologies and their connection to network technologies play a vital role in the long-term evolution of world system development characterized by both path-dependencies and major transformations that result from technological innovations. While digital information technologies significantly alter the processing and use of information as a central element of power and control within this network structure and therefore its network logic, they do not break the evolutionary process of world system development.

Keywords digitalization, technology, information and communication technology (ICT), world system development, digital capitalism, networks, information processing, hierarchy, sovereign states, path-dependence, evolution 


\section{Transformation through Information?}

The world system here is understood as a social system where mutual regularized interaction is important for the reproduction or change of any local structures (Friedman and Rowlands, 1977; Chase-Dunn and Hall, 1997). An important focus of the study of the development of world systems centers on it internal distribution of power (Modelski and Thompson, 1996). While the central position of leadership within the world system has periodically shifted, the question arises whether this leadership can still be exerted by single states, or is more likely to be manifested in other, alternative units.

This question becomes more complex in the light of the existence of new communication networks and digital technologies. The new "Information Age" is one in which the control of information becomes the most critical aspect of system development (Castles, 1996, Fn 3). It emerged out of a long historical evolutionary process (e.g., Hobart \& Schiffman, 1998; Wright, 2007). This fundamental change in the nature and structure of control at the macro level makes it important to view this as a new stage in the development of world systems.

Dating the start of the Information Age is difficult. It is often seen as beginning with innovations in communication technologies since the 1970s, or alternatively with the rise of digital information networks in the mid 1990s. Most participants in the debate agree on one thing: in the 21 st century, this system spans the entire globe. The focus is therefore on the question of the current and possible future development of the world system. Is the current state of chaos just part of the regular systemic transformation, perhaps similar to the one that took place with the rise of Europe in the sixteenth century? What impact will new, and especially digital technologies have on future world system development? 
These questions are crucial to the study of the future modus operandus and thus the means of control within the world system. Put differently, what will come to constitute power in the world system, and who can aim to wield it? Does systemic leadership continue to exert itself in a similar fashion as in the past — a single state possessing a disproportionate share of power in a system of states that acts as the overarching organizing principle of the world system — or should we expect new power-centers striving for the creation of far-reaching systems under their control, i.e., a return to empire-systems? To put these questions in a proper context, it is necessary to understand the structural formation and development of the world system, with a special focus on the type of linkages — or networks — that mark the development of the world system as a global "web of webs" (McNeill \& McNeill, 2003).

\section{The Structural Formation of the World System}

For Wallerstein $(1974,1980,2004$, cf. Skocpol 1977) and authors in his tradition (Chase-Dunn \& Hall, 1997; Hall, 2017; Hopkins \& Wallerstein, 1996; Thompson, 1983), the differentiae specificae of the world-system born out of sixteenth century Europe was the dynamics of the ceaseless accumulation of capital, a feature characterizing no other historical system that existed before. This view does not deny the existence of previous interaction networks. However, they are viewed as so systemically different in their operating principle that they need to be categorized as separate entities. From this perspective, the expansion of the world system into a truly global, all-encompassing social interaction network, including cultural, economic, and political relations, results in a new phase of world system development, marking the "end of the world as we know it”' (Wallerstein, 1999). This earlier literature on 'world-systems' hyphenates the term to differentiate it from mid-20th century social and political positions that treat states as essentially closed units. 
In this view, the source and location of power changes dramatically. Nation states lose their primary status, and thus their ability to structure the future development of the world system. The operational mode of production, and thus the critical mode of world-system development, is viewed as having shifted. The main unit of systemic development and control moves from the sovereign state to a multitude of possible alternative actors. However, whereto this system has shifted is still widely debated, whether to return to a proto-capitalist mode, or alternatively, to far more participatory and inclusive forms of global governance (Chase-Dunn \& Inoue, 2010).

An alternative view (Denemark, Friedman, Gills \& Modelski, 2000; Goldstein, 1988; Rennstich, 2008; Thompson, 2000) on the evolution of world systems argues instead that it is not primarily — the mode of production that determines the overall developmental patterns and outcomes, but the nature of the evolution of the world system itself - i.e. the evolutionary process of world system development — of which various modes of production, are only one element. In this view, the regularized interaction that characterizes a world system may envisage a number of modes of production without altering its fundamental structure. If one can accept this notion, world system development takes on an evolutionary character: the nature and the rules of the "game" - i.e., the process of world system evolution — do not change with the development of capitalism as much as is implied by the Wallersteinian world-system view of development (Frank and Gills 1993).

What does change are techniques of competition, of which the basic modi operandi have in fact been around for a considerably longer time than the sixteenth century. The actors merely change positions. From this perspective, systems change in character, largely driven by the kind of technological and organizational alterations described by Perez (2002) as a "technological style." A world system, in this view, is conceived of as the social organization united by basic 
institutions such as writing, cities, states, or state systems, technologies, or intersubsystem networks such as trading networks.

The singular perspective is based on the concept of a Kantian universal history of mankind and argues that the various human cultures have experienced a significant degree of interaction at every stage of their history - never more so than during great transformations of the world system. This view contrasts with a pluralistic perspective, of a number of more than twenty separate civilizations pursuing essentially independent careers (Wilkinson, 2000). For the purpose of the discussion here it is useful to allow for the Marxian concept of predominant mode of production to be used alongside the concept of technological styles which is based on evolutionary economics, as both play a critical role in the developmental process not only of societies but of the world system as a whole.

The evolutionary process of the mode of accumulation which establishes the major modes of production and exchange in agriculture, mining, industry, and other economic activities, has so far developed over a number of centuries or millennia (Denemark et al., 2000; Frank \& Gills, 1993; Hall, 2017; Morris, 2010). During this process, periods of productive development, and a surge of new technologies enabling new technological styles such as bronze or iron, alternate with others that expand networks of interchange by pioneering new trade routes, thus enabling the dispersion of innovations throughout the entire system over time.

A major shift in terms of the general mode of organization has taken place during the emergence of the modern era with from the decline of command economies and the move toward market structures. A number of authors (e.g., Castells, 1996; Rosecrance, 1999; Sassen, 2006; Rennstich, 2008; Cortada, 2009) suggest that another shift of similar magnitude is currently taking place as part of the transition from analog-based information to digital-based forms of 
information. As a result, the focus of much of the study of global politics turned away from state power considerations toward other forms of influence. The following section provides a discussion of power and leadership in a historical and world systemic context of such other forms (for alternative accounts, see e.g., Rosenau \& Singh, 2002).

\section{Power and Leadership in an Information Age World System}

Much of the history of the study of global politics finds power defined by mechanisms of force controlled by Westphalian states. Newer perspectives focus instead on cooperation rather than coercion. So-called "soft power" — the ability to attract and coopt — replaces "hard power" — in the form of coercive force - as the critical element in such an environment (Nye, 2004). From this perspective, the effects of complex interdependencies on the rules of engagement in a new, transforming and globalizing world system, and the rise of regional powers rather than the question of a possible single state challenge to the old hegemonic power status of the current leader, the United States, are of importance (Grant \& Keohane, 2005; Keohane, 1989).

Nye also argues for the need to put any discussion of power in the world system in the context of the information age and to recognize that the contemporary distribution of power resources varies greatly across different issues (Nye, 2004). From this perspective, the very concept of a single-center power in the traditional, coercive sense seems to have lost its explanatory or predictive strength. But through the introduction of new forms of power, it seems possible for the existing leader to substitute a declining form of power with capabilities in other power domains, thus securing its relative share of power in the system.

These analytical developments were largely the result of a division of labor in political science, where security studies focused largely on an independent system of sovereign states battling over 
hard power, and studies of the international political economy focused on the issues of soft power in overlapping, but mostly separate systems. As a result, many political scientists lacked interest in the world(-)systems-based and other long-term structural systemic concepts of hegemonic power and systemic leadership in the realms of both hard and soft power.

However, the lack of an emergent new world order after the fall of the Berlin Wall, and the aftermath of 9/11 muddled the analytical waters. Not surprisingly, the concepts of hegemony and world system leadership have seen a resurgence in both academic and popular treatments (Chomsky, 2003; Ferguson, 2004; Hardt \& Negri, 2000; Johnson, 2005). While it is true that the constituting elements of an interdependent world have not suddenly vanished, recent events in world politics — the American but also European responses to the 9/11 attacks, the rise of China as a regional, and now expressly also global power, to name but a few - have demonstrated the continued role and importance of traditional - i.e., coercive capabilities for the establishment and projection of power in the new world system.

The disproportionate massing of a traditionally critical set of capabilities in a single and similarly traditional unit — the modern sovereign state — has brought back the analytical focus on the need for a thorough understanding of the historical and cyclical system of world system leadership. However, just as in the political science literature, scholars more traditionally associated with the question of global hegemony struggled throughout the 1990s to connect the world they seemed to experience with the traditional world-system concepts. Some declared an age of transition, and as previously remarked even the end of the world as we know it (Hopkins \& Wallerstein, 1996).

The world system school does not lack for ideas on the interaction between the hard power of the state and the various soft power options offered by the study of the global political economy. 
Wallerstein argued early on for the concept of hegemony as resulting from the confluence of agricultural, manufacturing, and financial power. His analyses do not lack a geopolitical content (Wallerstein, 1991). Giovanni Arrighi outlined a process where systemic cycles of accumulation, driven by different formulations of internationalization of military and production systems, give rise to different eras (Arrighi, 1994). In terms of technology itself, Modelski and Thompson's (1996) conceptualization of the long leadership cycle is most important. For Modelski and Thompson, significant technological innovations alter the nature of the global economy in fundamental ways and generate the wealth and status needed to propel their founders to positions of global leadership. Global leaders are those that use their wealth and status to set the global agenda. As economic innovations disperse, power wanes and the lead economy is often challenged militarily. Their success drives another lead-economic cycle. As a result, two innovation-driven economic cycles (of approximately 50 years each) constitute a single long political leadership cycle (of about 100 years). Britain was the only system leader to repeat the process and enjoy two long leadership cycles.

This shift in the geographical and socio-political location of power has been explained as the outcome of the leader's experience of success in the current setting, creating an entrenched institutional bloc that proves adaptive in defending its turf but less so in fostering the rise of new leading sectors. It is important in this context to keep the evolutionary development of the world system in mind: leadership during the early stages of the weaving of the world system required different capabilities and took different forms than the exercise of a disproportionate share of power in the network-centric system in existence in the early 21 st century (Göransson \& Söderberg, 2005; Rennstich, 2002; Rosecrance, 1999). This development also is by no means linear but relies on dynamic patterns of development (Devezas \& Corredine, 2002). 
Being able to exercise leadership in the global web of 2020 does not simply require $\mathrm{x}$-times more capabilities than it did in the 1800 s. Rather, it is important to differentiate between divergent types of capabilities, different forms of power and control, and as a result different concepts of what establishes leadership of the world system and thus the ability to (re)shape its structure (Modelski \& Thompson, 1996). Whereas previous innovations and technologies that developed into new leading sectors dominating the development of the world system were largely enablers of external network expansion, and thus mostly about trade, the leading sectors and their accompanying technologies of the industrial phase had to allow control of complexity on a much larger scale (Rennstich, 2005a).

This transition can best be viewed in the structural change of textile manufacturing under British organization. In the seventeenth and eighteenth centuries, factories set up by the English East India Company on the (eastern) outer realms of the British-controlled and thus Europeancentered network of the world economy spanned entire continents and included a sophisticated system of financing and the outsourcing of production to independent contractors. In the latter half of the eighteenth and into the nineteenth century, this production system was replaced by factories organized around individual firms in the center of a less externally-oriented, but more vertically integrated world-economy with its center in Britain and later the United States. With the increasing demise and unraveling of the Fordist model (of internal networks), beginning in the 1970s, the punctuation of the global system seemed to have given birth to a new phase of extending external network dominance (Rennstich, 2005b). Whereas the Japanese manufacturing mastery in the 1970s and 1980s was based on internal network management, the parallel development, mainly in the high-tech regions of the United States, created a new open systems business model. This created the decentralized environment for the emergence of new innovative clusters that allowed for the crucial diffusion characteristic of all previous new 
leading sector developments. Initially these external networks remained mainly within the boundaries of national economies, with networking emerging as a means of coordination enhancing the resource creation activities of enterprises. Later on, however, these networks increasingly extended across national borders and regions. Fostered by the rise of digital communication interfaces — including mobile technologies — lowering significantly the cost of access, the creation of open systems, and the availability of standardized and truly global logistical solutions, a multitude of cost-efficient organizational open systems have replaced previously closed or national systems (Rennstich, 2008).

One of the main characteristics of systemic leadership transitions in most treatments of the subject seems to be the inability of the existing leader to establish a similar position in a newly emerging and structurally different commercial and organizational environment. This shift in the geographical and political location of power has been explained as the outcome of the leader's experience of success, creating an entrenched institutional setting (in a broader sense) that proves adaptive in defending its turf but less so in fostering the rise of new leading sectors (Rennstich, 2004).

However, the case of Britain's continued leadership over an extended period of time (and separate long waves) has shown that this is not always the case (Rasler \& Thompson, 1994). This has been attributed to the occurrence of a switch from one network system to another (Rennstich, 2004), itself the result from the change in the type of production that tied Britain to the overall mode of global web weaving. A similar transition seems to be taking place during the first half of the 21 st century. The possibility of dominance over network flows therefore seems to extend, at least in the foreseeable future, the ability of states in general, and to the U.S. in particular, to 
continue not only their dominant position within the world system, but also their ability to yield important control over the structure of the world system as a whole.

As a result, it is important that we come to understand the nature of information and information technology both as a current lead sector, and as regards the effect such technologies will have on the development of subsequent lead sectors. The following section will discuss the vital role information and carrier technologies based on new forms of information technologies and their connection to network technologies play in the evolution of world system development. This is followed by a discussion of new leading sectors and their implication for power and its constitution in the newly evolving world system.

\section{The Role of Information and Information Technologies in World System Development}

The pace of the inner-most process in the world system, captured in the successive development of Kontratieff-waves or K-waves (Barnett, 1998; Goldstein, 1988; Thompson, 1990; Tinbergen, 1983), is determined by cognitive and generational biological control parameters (Devezas \& Modelski, 2003).

(1) cognitive - impacts collective learning, driving the rate of exchanging and processing information at the microlevel; and

(2) generational - the development of successive human cohorts constrain the rate of transfer of knowledge (or in other words, information integrated into a context passed between successive generations at the macrolevel).

These parameters rest on the dynamics of information and knowledge. Information and knowledge are two separate but intertwined concepts, and the centrality of both in the 
developmental process of the world system requires a close consideration, especially in any suggested "Information Age" (Hidalgo, 2015; Kahin \& Foray, 2006; see e.g., Wright, 2007).

Information, from a mathematical and scientific view, refers to the reduction of uncertainty in a communication system (Shannon, 1948). It thus includes any pattern of energy or matter we can find in nature as a container of information. Information should not be confused with knowledge. Knowledge refers to ideas and facts that the human mind has internalized and understood, often acquired and assembled in a complex fashion. Knowledge is a complexity that is nearly impossible to simulate in a mechanical fashion — i.e., via artificial intelligence (AI). It is, in other words, information embedded into a larger socio-economic, cultural, and political context. As societies grow more complex and the amount of accumulated knowledge rises, the need for information handling becomes an important determinate of successful organization (Headrick, 2000). Rather than aiming to identify a starting point for a knowledge society characterized by the rise of an information era it seems more useful to view the entire development of humankind in terms of the growth of a knowledge society. This development has not been linear, but rather a process marked by periods of sharp accelerations in the amount of information that people had access to, and in the creation of information systems to deal with it. To understand the evolution of the world system marked by the rise of the new global digital network it is thus necessary to have an understanding of the forms of information systems that mark its development.

According to Innis (1950), in one of the seminal texts on this subject, a crucial element of the interaction between cultures - i.e., different social groups that have embedded information as knowledge in different contexts — is their adoption and use of different communication systems to control space of place as well as space in the sense of group identity and boundaries. Headrick (2000) defines information systems as the methods and techniques by which people organize and 
manage information, rather than the content of the information itself. Information systems in this understanding are supplements of the mental functions of thought, memory, and speech, and thus the technologies of knowledge. He uses five dimensions on which to categorize information systems, namely information

(1) gathering;

(2) classification;

(3) transformation;

(4) storage; and

(5) communication.

Employing these dimensions, he identifies the rise of a new information system in the period from 1700 to 1850 , driven as were the previous information systems by the combination of information-demand, -supply, and organization. This new information system ultimately provided the basis for the digital informational system that is now emerging. Hobart \& Schiffman (1998) highlight the rise of a distinct new information system based on its digital character rooted in the cultural and technological developments of the eighteenth and nineteenth centuries. In this system, information no longer acts as a universal, abstract model of the world, either classificatory or analytical, but rather has become a world unto itself, in which abstract symbols can be assigned arbitrarily to any objects and procedures whatsoever.

As an important precursor, the rise of relational mathematics in the modern age realized the information potential of numbers. Relational mathematics allowed for new forms of information organization in a broad-reaching, reductionist hierarchy fashion. Digital information has elicited the information potential of purely abstract symbols even further, fabricating a realm of pure technique apart from any foundation in knowledge in the traditional sense, that is as a reference 
to knowledge stored in other forms accessible without mediation by humans. This has important consequences for the type of networks that manifest the world system, discussed in more depth in the following section.

\section{The Role of Networks on the Development of the World System}

In effect, the world system is made up of a variety of complex intraorganizational and interorganizational networks — or webs — intersecting with geographical networks structured particularly around linked clusters of socioeconomic activity (Cioffi-Revilla \& Merritt, 1981; Cioffi-Revilla, Merritt, \& Zinnes, 1987; Gunaratne, 2002). These networks are at once characterized by both path-dependencies and major transformations that result from technological innovations, especially in related areas of transportation and communication (McNeill \& McNeill, 2003; Modelski \& Thompson, 1996; Rennstich, 2005b; Thompson, 2000). For a better understanding of the world system in the information age, it is therefore necessary to get a better understanding of the close relationship between communication and transportation networks.

Hugill (1999) emphasizes the two-way flows of information that predominate as mechanisms of military - i.e., political — and economic control. He argues that the geopolitical interests of 'trading states' that exert their power mainly in external networks, and 'territorial states' that are internally network-based, differ in terms of the military and communications systems they employ. Whereas trading states have an interest in exerting weak control over long distances, territorial states wish to exert strong control over short distances. The former thus tend to invest in long-range military and communications systems, seeking to establish external networks of control. 
The pattern of existing technology being transformed in innovative spurts and clusters proves the breeding ground for the emergence of a new dynamics of world system development. Spar (2001) connects the ventures of Portuguese explorers of the fifteenth century to the development of the telegraph and radio in the middle of the nineteenth century, and the advent of satellite television and the internet in the twentieth century. She identifies a common dynamic in the development of new information systems, with bursts of innovation at the beginning, creating new commercial opportunities, creating a gap between economic, social, and technological activity and political control, with economic and technological development driving the political advancement of the system.

Hall \& Preston (1988) make a similar argument that the origins of the newly emerging system must be traced back to the transformations in communication technologies beginning roughly in the around the middle of the nineteenth century, with the invention of the electrical telegraph (1830s), the telephone, typewriter, and phonograph (1875-1890). These new inventions marked the emergence of what the authors call "New Information Technology" industries, embracing the full range of mechanical and electrical mechanisms that record, transmit, process, and distribute information.

\section{Digital Network Logic}

Some authors (e.g., Hall \& Preston, 1988) have argued that the information infrastructure may be just as important as the infrastructure of physical transport, or even more so. What differentiates the currently developing technological style from previous forms is its digital nature. This affects its scale geographically, as well as the units it connects, and its impact on the creation of new leading sectors. 
Network Economics

What characterizes and distinguishes network-centric markets from others are the issues of (Shy, 2001, p. 1):

(1) complementarity, compatibility, and standards;

(2) consumption externalities;

(3) switching costs and lock-in; and

(4) significant economies of scale in production.

Goods and services that are part of network markets should thus be viewed as 'systems of complements' rather than individual products, for example computer hardware and digital software or Digital Versatile Disc [DVD] players and DVDs. One is relatively useless without the other. The real use of the services or items only comes into effect within a system. This raises the need for compatibility (e.g., software running on certain hardware platforms, cable connections featuring compatible designs) and thus raises the issue of common standards and the need for coordination. Questions of coordination and standards rapidly become crucial in network markets.

These standards in turn unlock the unique features of network externalities, which can profoundly affect the market behavior of firms and individuals. Once users of these systems have invested into their use by obtaining certain technology, licensing contracts, training and learning, etc., they experience "lock-in" because switching costs from one system to another can be relatively high and require search costs, reinvestments, and loyalty costs. At the same time, this standards-based lock-in does enable new technologies to emerge as part of the evolutionary development of network-dependent technologies (Lee \& Sohn, 2018). 
Switching costs affect price competition in two opposing ways. First, in the case of already locked-in customers, firms may raise prices knowing that consumers will not switch unless the price difference exceeds the costs of switching to an alternative system. Second, in case of consumers not yet locked-into one system, systems-providers/sellers will compete fiercely (e.g., through discounts, free trials, free complimentary products and services, etc.) in order to attract customers and create a critical mass of customers locked into the providers/sellers system). In economic terms, the combination of often very high fixed sunk costs with almost negligible marginal costs implies that the average cost function declines sharply with the number of items sold. Once a critical mass is obtained, network markets can be extremely profitable.

Since all successful networks rely on a critical mass to develop their network externalities (i.e., when the value of a good depends on the number of other people who use it) and thus raise the value of the offered system, the establishment and control of standards becomes a key determinant of commercial success. The convergence between organizational requirements and technological change has established networking as the fundamental form of competition in the now truly globalized economy (Hatzichronoglou, 1996). Those networks also act as gatekeepers. Barriers to entry into the most advanced industries such as electronics or biotechnology have skyrocketed, making it extremely difficult for challengers to enter the market by themselves. It even hampers the ability of large corporations to open up new product lines or to offer their own processes in accordance with the pace of technological change. This is best demonstrated in the case of biotechnology.

Cooperation and networking offer the possibility of sharing costs and risks, as well as to keeping up with constantly renewed information. Inside the networks, new possibilities are abundant. Outside the networks, survival is increasingly difficult. Under the conditions of fast 
technological change, networks, not firms, have become the actual operating unit. However, firms continue to be the main organizational framework. It is the form of the corporate organizational structure that changes, not the role of the corporation as the organizational structure (Castells, 1996). The role of the network, or what Castells (1996) calls the networking logic, therefore substantially changes the character of the global economic environment.

Whereas traditional rules of competitive strategy focus on competitors, suppliers, and customers, companies selling complementary components in the informational network economy become equally important. Cross-national production networks permit firms to weave together the constituent elements of the value-chain into competitively effective new production systems, while facilitating diverse points of innovation. Large segments of complex manufacturing technology itself becomes a commodity available in the market. Taken together with the above discussed merging of all networks into one digital web of webs, (or supra-network), the global network and its digital information infrastructure enables the merging of many different markets, both on a horizontal and vertical scale.

\section{Protocols and Standards}

In markets driven by network economies, standards and protocols reign supreme (Brousseau \& Curien, 2007; Brynjolfsson \& Kahin, 2000; Latham \& Sassen, 2005; Talalay, Farrands, \& Tooze, 1997). The transition from an internal network system to one based on an external network, is not only reflected in the structure of economic organization, but also in the kinds of networks themselves (Borrus \& Zysman, 1997). Provider-supplied networks are defined and controlled by the network company that offers a given set of services. User-driven networks are at least in part defined and controlled by the user who designs them to fulfill specific functions. 
These user-driven networks generate a competitive market for the system and often constitute disruptive technologies - i.e., technologies that establish a new lineage and force users into a new network. In this respect, provider-supplied networks such as the telegraph or early telephone networks were the natural extension of industries based on an internal networking logic. The control over the network and its systems was regarded essential for its control. By contrast, userdriven networks are much more attuned to an external networking logic, since they allow for competing systems relying on a set of standards that allow and enable end-to-end interoperability of the communications infrastructure. Suppliers in such an environment rely on open-but-owned systems: open at the interface to permit interconnection of systems from other vendors but owned to reap a return from innovation. In short, users demanded highly functional and interoperable systems.

The classic example of the transition from dominance of system providers controlling the valuechain to dominance of standard setters in the disintegrated value chain is the rise of the Wintel standard — the interdependent double technological quasi-monopoly of Intel computer chips and Windows operating software — accompanying the personal computer (PC) revolution. Rather than controlling the production of entire systems, as was traditionally the case in the information processing industry, IBM's personal computer strategy encouraged the provision of alternative system provision to ensure a faster growth of the overall platform. This allowed the main critical component providers - Intel for the hardware and Microsoft for the software — to set the standards that enabled the interoperability of the various system component providers, that is, hardware and software providers competing against alternative computing systems.

A crucial factor allowing firms to wage — and win — a war of standards is an advantage in intellectual capital, or put differently, control over intellectual property rights and patents, the 
main currency of control and power in the information age. The importance of standards and protocols has been widely theorized and studied by Lessig (1999), who argues that code becomes governing law and as such becomes an object of the traditional manifestation of political control. His work rightly predicted not only the interest and ability of private actors such as firms as well as individuals in obtaining control over these standards, but also their interest to and partial capture by governing institutions, most significantly nation states (see also discussions of this question in Post, 1995; Sassen, 2006).

New Technologies and Leading Sectors

Most authors who study current and future world system development stress the importance of information and communication technology (ICT) as a new leading sector (Bornschier \& ChaseDunn, 1999; Freeman, 1983; Hall, 1985; Bruckmann, 1987; Goldstein, 1988; Modelski \& Thompson, 1996; Lipsey, 1999; Mensch, 1979; Rennstich, 2008; Tinbergen, 1983). A leading sector is not necessarily very large in comparison to other economic sectors. What determines the leadership role of a sector is whether its impact on growth tends to be disproportionate in its early stages of development.

Although the establishment of a new leading economic sector will initially require more significant investment than its early output would seem to justify, the expected long-term returns provide incentives for investors to make the necessary resources available. As the sector continues to exploit its particular contribution to efficiency and productivity, its linkage to overall economic growth should stabilize. Most of these authors focus on the hardware side of ICT: microprocessors, electronic components, etc. Others include software, as well as a new sector made possible only by recent developments in ICT, biotechnology. As in earlier leading 
sectors, we can trace the development of ICTs through various K-waves. Hall \& Preston (1988) show how information technology emerged through the last four K-waves, beginning with the development of the telegraph in the 1830s. Standage (1998) traces the modern internet back to the mid-1800s with the development of a telegraph network.

However, simply identifying ICT industries as a lead sector is not sufficient. Many countries, and certainly all the likely candidates for systemic leadership, now realize the strategic importance of ICT and try to develop their industries accordingly. What is crucial is the emergence of an appropriate socio-economic complex (Freeman \& Louçã, 2001; Perez, 2002). This is the combination of the creation of economic innovation and fostering socio-political institutions form the nucleus of a new technological style. As a result, these complexes also foster the development of a head start in emerging leading sector development. (States in the past obtained leadership positions through the establishment of a supportive and enabling institutional environment for innovating agents, such as individuals and firms.) This combination of private and public institutions can under certain circumstances foster the innovational milieu that leads to the clustering of economic and socio-political innovations, which in turn can lead to the development of new leading sectors, and ultimately the development of a new technological style, such as biotechnology (see Cooke, 2006).

The development of a dominant economy based on these leading sectors formed the foundation of political and economic leadership in the world economy. Britain's success during the period of the Industrial Revolution was well observed by other states at the time. However, nowhere were these improvements so widespread and effective as in Britain, in part a result of a unique complex of formal and informal institutions. Britain featured the optimal set of institutions to allow for the development of a new socio-economic paradigm of doing things better and more 
efficiently. This enabled Britain to set new standards for a new technological style. This also holds true for the development of leading sectors in the information era, namely ICT, networking, biotechnology, and the development of new energy forms (Rennstich, 2008). We discuss the first three of these in the section on the internet and biotechnology.

What characterizes the new phase of world system development is not so much the centrality of knowledge and information, but the application of such knowledge and information to knowledge generation and information processing/communication devices, in a cumulative feedback loop between innovation and the use of innovation. Whereas the leading sectors of earlier external network dominated K-waves, like the Baltic, Atlantic, and later the Eastern trade routes, were dominantly maritime, the leading sector of this period are increasingly turning into digital commercial trade routes (Rennstich, 2005b). A critical part of this digital network is the internet.

\section{The Internet}

The internet on the one hand serves as a network resembling more traditional trade routes in the sense that the new commodity of the newly emerging, digital information-based long-wave is transported along its lines (Hidalgo, 2015; Rennstich, 2008). However, information itself is not the only commodity. E-commerce, or the electronically enabled retailing of software, digital books, digital services such as online-brokering and e-banking, and digital outsourcing of formerly key internal administrative tasks, are now common phenomena. It is reasonable to add the growing number of web-enabled transactions (e-business) of non-digital items and services, both business-to-business and consumer-to-business, to this count. In sum, the internet as infrastructure and enabler of networking already constitutes a significant global digital trade 
route and is increasingly developing into the central interchange circuit not only for commercial exchange but also for almost all other forms of human interaction. On the other hand, however, the internet also creates a new global commons, an area that has become a collaborative space that resembles cities and ports as focal points of connections in more traditional networks as places in which critical elements for value creation in services and manufacturing come together.

From its roots as a U.S. defense network, to its role as an international virtual college of scientific and academic researchers, to the globally expanding World Wide Web (WWW), the history of the internet has been one of exponential growth in both number of users and number of hosts connected to the network (Abbate, 1999; Berners-Lee \& Fischetti, 1999). In essence, the internet is a network of networks. Its most important feature is a set of standardized protocols, i.e., conventions by which computers exchange data, sliced into little packets, over various kinds of carriers. Central to the success of the internet was the development of two main protocols governing this process: IP (Internet Protocol) and TCP (Transmission Control Protocol). Other protocols, such as the Hypertext Markup Language (HTML) or the domain name system governed by the Internet Assigned Number Authority (IANA) have proven equally important.

While still dominated by the United States in terms of technologies, the internet is now widely accessible and integrated tightly into existing global economic production and consumer structures. The U.S. still informally maintains its central role of this global network even though its public governance has steadily been internationalized (Bradshaw, DeNardis, Hampson, Jardine, \& Raymond, 2015; DeNardis, 2014; Mueller, 2010; Nye, 2014). Whereas every region and nearly every country is now tied into the digital network in the form of a direct internet connection to the United States, direct connections between other regions or countries are less common. This is easily viewed when noting the lack of direct internet connections between 
Europe and Asia. As a result, the United States still serves as a central switching facility for interregional data traffic and thus as a central node of the digital external network system (Townsend, 2001a), even though this position is changing based on new network structures developments such as more direct linkages through sea-cable based networks (OECD, 2013, pp. 151-155).

Also important in the larger context of the historical development of the world system is the reemergence of major cities as important nodes of the external network development (Kitchin, Lauriault, \& McArdle, 2017; Sassen, 2002; Townsend, 2001b). During the transition from an internal network-based system to an external-based one, so called global cities acted mainly as sites where transnational flows of goods, capital, and people were tied into national and regional economies. Put differently, cities were network nodes. Evidence exists to demonstrate that new telecommunications networks reflect a more complex system of interurban information flows than implied by earlier works centering on the global city hypothesis, connecting a wider range of cities in a more complex way (Sassen, 2002; Scott, Agnew, Soja, \& Storper, 2001). This renewed focus on a center and hinterlands structure of the global system, as well as the geographic centrality of the United States for functioning and control, makes it clear that despite its increasingly digital nature, the global system is still very much a geopolitical one in the traditional sense of the meaning (Barnett, 2001).

Geography continues to matter as an organizing principle and as a constituent of social relations (Csurgai, 2017; Mitchell \& Kallio, 2017). It cannot be eliminated entirely because of the interaction of the virtual space with the world beyond ICT networks and cyberspace, which only in combination constitute the external networks upon which the global world system is based. Increases in capacity, speed, and digitalization, have provided possibilities to integrate graphics, 
text, video, and sound — including voice — in applications, while the integration of computing and communication technologies has created possibilities of accessing and using interactively services and applications. Increasing bandwidth and speeds now permit transport integration and unprecedented flexibility and performance in network use as infrastructure to economic activities. The trend towards large numbers of highly sophisticated devices increasingly relying upon a network also constitutes a discontinuous transformation in the demands being placed upon the network infrastructure in terms of both the transmission volumes and the new pattern of use it will have to accommodate.

With the increasing sophistication of the mobile-based technology, the "poor man's email" (the Short Message System or 'texting') using regular mobile phone networks and its further development into mobile data network-based messaging using apps such as WhatsApp, Signal, etc. - has become the interface of choice for access to the digital commercial system for many users outside of the U.S., and increasingly there as well (Rennstich, 2008, p. 111). Now firmly integrated into other existing technologies of the digital nervous central system, this technology has allowed the essential integration of the hinterlands into the major center network. A digital divide is certainly a reality in terms of level of integration, both in width and depth. It is, however, by now a divide that is being bridged by new forms of digital technologies of different levels of sophistication, creating together a truly global digital external network system (Donner, 2008).

\section{Biotechnology}

Following in the footsteps of the rise of ICT as a leading sector, and to a large degree now intricately interwoven with this technology (Wessner, 2001), the biotechnology industry can 
trace its origin in its current form back to the late 1960s and early 1970s (Ouzounis \& Valencia, 2003). The scientific results enabling genetic engineering techniques built upon more than twenty years of basic research in molecular biology, microbiology, and related work on DNA (deoxyribonucleic acid), genes, and cells (McKelvey, 2000). The genetic engineering techniques developed in the 1970s enabled controlled changes to DNA and followed the logic that molecular biologists had identified before they possessed practical techniques.

Alongside basic research unlocking the genetic information of molecules such as DNA, the commercial uses of genetic engineering, mainly for the production of pharmaceuticals, began to develop in the 1970s. Often seen as the start of the new biotech industry, the 1976 founding of the Californian biotech firm Genentech provided a model in which basic scientists and venture capitalists joined together. In general, these firms would sell R\&D contracts to established firms in order to develop new scientific knowledge and techniques for the use and adaptation of scientific activities to commercial purposes.

Up until the mid-1980s, most biologists had little use for computers other than to communicate, and then to compare DNA sequences. In the late 1980s, however, a significant transformation within biomedical science finally became a widespread phenomenon, namely the computerenabled shift from single-gene studies to experiments involving thousands of genes at a time, from small-scale academic studies to industrial-scale ones, and from a molecular approach to life to an information-based one, highly dependent on sophisticated computing and processing power (McKelvey, 2000).

Now, biology, electronics, and informatics are converging and interacting in their applications, in their materials, and in their conceptual approach (Matzke, 2013). In addition, the manipulation and duplication of genes and genetic patterns - i.e., cloning and recombination — has become a 
standardized technical process as shown for example in the so-called "clustered, regularly interspaced, short palindromic repeat" (CRISPR) technique (Sander \& Joung, 2014). Technological advances have made it possible to increase productivity and yield of biotechnical processes substantially to such a degree that by now biotechnology in industrial production is firmly established, especially for the conversion of natural raw materials and for the production of highly-priced specialities (Soetaert \& Vandamme, 2010). The convergence of supercomputers, advanced mathematics and robotics has made possible the fully automatized process of mapping genomes, creating vast amounts of biological data. These data are now at the center of the most important commercial area on the software side of biotechnology, bioinformatics (Perez-Iratxeta, Andrade-Navarro, \& Wren, 2007).

Bioinformatics is a spectrum of technologies covering such things as computer architecture, storage and data-management systems, knowledge management and collaboration tools, and the life science equipment needed to handle biological samples. Bioinformatics companies sell both software and services for manipulating the relevant data. Most do not produce any novel data themselves: they only find ways to transform other organizations' data. Biological data are flooding in at an unprecedented rate and biotechnology is now mainly an information industry (Bansal, 2005; Tripathi, 2000). New partnerships between IT and biotech companies are being formed at a very fast rate, as we would expect from both our global system process model, anticipating an innovative surge of commercial activity in this area, and general evolutionary organizational innovation models (Devezas, 2005; Dosi, Freeman, Nelson, Silverberg, \& Soete, 1988; Nelson, Winter, \& Schuette, 1976). The list covers bioinformatics, DNA microarrays (gene chips), data analysis and visualization, chemical and biological library integration, detection of human genetic variation (SNPs), microfluidics, and in silico (computer modeling or simulated experimental) research. 


\section{Summary}

Globalization as a concept has long taken on such a generic meaning with quite drastically different connotations depending on the school of thought behind the analysis, that it seems to have lost its analytical cache. For students of world system development, however, the creation of a single world system that now spans the entire globe still remains a critical analytical framework for good reasons. It allows us to conduct the analysis of current phenomena using insights from the evolutionary development of said world system that takes into account not only past patterns of development, but also to draw on our comprehension of the importance of the dynamic structure of these processes as well as their interlinkages and feedbacks. This article has provided answers to the question of the current and possible future development of the world system taking account of these patterns to address the issue whether what we observe today in the current state of world affairs represents merely "global chaos" or whether it is part of the regular systemic transformation that we have observed and analytically and empirically observed over the last couple of millennia. It has argued for and presented the kind of transformative effect digital technologies have likely on future world system development as a continuous yet also disruptive process (as in previous instances), focusing on the core processes - the pathway of world system evolution and technology and networks play in it historically as well as today — as well as the importance of the transformation of information taking on a digital gestalt. The internet as simultaneously a global commons and global economic exchange network takes on a special place in this development. Similarly, the role of biotechnology and its impact on the biological developmental patterns in light of its transformation of a continued abstractinformation process puts "data" in the center of social and economic processes in the current and 
future world system. In doing so, it provides a crucial interface between the digital realm and biological realms of our social world that as in the past, today and in the future will remain — at least for the foreseeable future - the core basis of any world system, no matter what kinds of technologies digital or otherwise will continue to shape the evolution of the world system.

\section{References}

Abbate, J. (1999). Inventing the Internet. Cambridge, MA: MIT Press.

Arrighi, G. (1994). The long twentieth century: Money, power, and the origins of our times. London: Verso.

Bansal, A. K. (2005). Bioinformatics in microbial biotechnology a mini review. Microbial Cell Factories, 4, 19. https://doi.org/10.1186/1475-2859-4-19

Barnett, G. A. (2001). A longitudinal analysis of the international telecommunication network, 1978-1996. American Behavioral Scientist, 44(10), 1638-1655.

https://doi.org/10.1177/0002764201044010007

Barnett, V. (1998). Kondratiev and the dynamics of economic development: Long cycles and industrial growth in historical context. New York: St. Martin's Press.

Berners-Lee, T., \& Fischetti, M. (1999). Weaving the web: The original design and ultimate destiny of the world wide web by its inventor. San Francisco: HarperCollins.

Bornschier, V., \& Chase-Dunn, C. K. (Eds.). (1999). The future of global conflict. London: Sage. 
Borrus, M., \& Zysman, J. (1997). Wintelism and the Changing Terms of Global Competition: Prototype of the Future? Working Paper $96 B$.

Bradshaw, S., DeNardis, L., Hampson, F. O., Jardine, E., \& Raymond, M. (2015). The emergence of contention in global internet governance (Global commission on internet governance paper series No. No. 17) (p. 28). London: Global Commission of Internet Governance. Retrieved from https://core.ac.uk/download/pdf/28949117.pdf

Brousseau, É., \& Curien, N. (Eds.). (2007). Internet and digital economics. Cambridge, UK: Cambridge University Press.

Brynjolfsson, E., \& Kahin, B. (Eds.). (2000). Understanding the digital economy: Data, tools, and research. Cambridge, MA: MIT Press.

Castells, M. (1996). The rise of the network society (the information age: Economy, society, and culture) (1st ed., Vol. 1). Malden, MA: Blackwell.

Chase-Dunn, C. K., \& Hall, T. D. (1997). Rise and demise: Comparing world-systems. Boulder, CO: Westview.

Chase-Dunn, C. K., \& Inoue, H. (2010). Accelerating Global State Formation and Global Democracy (IROWS Working Paper No. 55). Riverside, CA: Institute for Research on WorldSystems, University of California-Riverside.

Chomsky, N. (2003). Hegemony or survival: America's quest for global dominance (the American empire project). Metropolitan.

Cioffi-Revilla, C. A., \& Merritt, R. L. (1981). Communications research and the new world information order. Journal of International Affairs, 35(2), 225-246. 
Cioffi-Revilla, C. A., Merritt, R. L., \& Zinnes, D. A. (Eds.). (1987). Communication and interaction in global politics. Beverly Hills: Sage.

Cooke, P. (2006). Global bioregions: Knowledge domains, capabilities and innovation system networks. Industry and Innovation, 13(4), 437-458.

Cortada, J. W. (2009). How societies embrace information technology. Hoboken, NJ: Wiley.

Csurgai, G. (2017). The increasing importance of geoeconomics in power rivalries in the twentyfirst century. Geopolitics, 23(1), 38-46. https://doi.org/10.1080/14650045.2017.1359547

DeNardis, L. (2014). The global war for Internet governance. New Haven: Yale University Press.

Denemark, R. A., Friedman, J., Gills, B. K., \& Modelski, G. (Eds.). (2000). World system history: The social science of long-term change. New York: Routledge.

Devezas, T. C. (2005). Evolutionary theory of technological change: State-of-the-art and new approaches. Technological Forecasting and Social Change, 72(9), 1137-1152.

https://doi.org/10.1016/j.techfore.2004.10.006

Devezas, T. C., \& Corredine, J. T. (2002). The nonlinear dynamics of technoeconomic systems: An informational interpretation. Technological Forecasting and Social Change, 69(4), 317-357. https://doi.org/10.1016/S0040-1625(01)00155-X

Devezas, T. C., \& Modelski, G. (2003). Power law behavior and world system evolution: A millennial learning process. Technological Forecasting \& Social Change, 70(9), 819-859. https://doi.org/10.1016/S0040-1625(03)00011-8 
Donner, J. (2008). Research approaches to mobile use in the developing world: A review of the literature. The Information Society, 24(3), 140-159. https://doi.org/10.1080/01972240802019970

Dosi, G., Freeman, C., Nelson, R. R., Silverberg, G., \& Soete, L. L. G. (Eds.). (1988). Technical change and economic theory. London: Pinter.

Dunn, M., Mauer, V., \& Krishna-Hensel, S. F. (Eds.). (2007). Power and security in the information age: Investigating the role of the state in cyberspace. London: Ashgate.

Everard, J. (2000). Virtual states: The internet and the boundaries of the nation-state. New York: Taylor \& Francis.

Ferguson, N. (2004). Colossus: The price of America's empire. New York: Penguin.

Frank, A. G., \& Gills, B. K. (Eds.). (1993). The world system: Five hundred years or five thousand? London: Routledge.

Freeman, C. (1983). Long waves in the world economy. London: Butterworths.

Freeman, C., \& Louçã, F. (2001). As time goes by: From the industrial revolutions to the information revolution. Oxford, UK: Oxford University Press.

Fukuyama, F. (1992). The end of history and the last man. New York: Free Press.

Goldstein, J. S. (1988). Long cycles: Prosperity and war in the modern age. New Haven, CT: Yale University Press.

Göransson, B., \& Söderberg, J. (2005). Long waves and information technologieson the transition towards the information society. Technovation, 25(3), 203-211. 
Grant, R. W., \& Keohane, R. O. (2005). Accountability and abuses of power in world politics. American Political Science Review, 99(1), 29-43. https://doi.org/10.1017.S0003055405051476

Gunaratne, S. A. (2002). An evolving triadic world: A theoretical framework for global communication research. Journal of World-Systems Research, 8(3), 330-365.

https://doi.org/10.5195/jwsr.2002.267

Hall, P. G. (1985). The Geography of the Fifth Kondratieff. In P. G. Hall \& A. R. Markusen (Eds.), Silicon landscapes (pp. 12-32). Boston: Allen and Unwin.

Hall, P. G., \& Preston, P. (1988). The carrier wave: New information technology and the geography of innovation, 1846-2003. London: Unwin Hyman.

Hall, T. D. (Ed.). (2017). Comparing globalizations: Historical and world-system approaches. New York: Springer.

Hall, T. D., Kardulias, P. N., \& Chase-Dunn, C. (2011). World-systems analysis and archaeology: Continuing the dialogue. Journal of Archaeological Research, 19(3), 233-279. https://doi.org/10.1007/s10814-010-9047-5

Hardt, M., \& Negri, A. (2000). Empire. Cambridge: Harvard University Press.

Hatzichronoglou, T. (1996). Globalisation and competitiveness: Relevant indicators (OECD science, technology and industry working papers No. 1996/05) (p. 61). Paris: Organisation for Economic Co-operation and Development (OECD). https://doi.org/10.1787/885511061376

Headrick, D. R. (2000). When information came of age: Technologies of knowledge in the age of reason and revolution, 1700-1850. Oxford: Oxford University Press. 
Hidalgo, C. A. (2015). Why information grows: The evolution of order, from atoms to economies. New York: Basic Books.

Hobart, M. E., \& Schiffman, Z. S. (1998). Information ages: Literacy, numeracy, and the computer revolution. Baltimore: Johns Hopkins University Press.

Hopkins, T. K., \& Wallerstein, I. M. (Eds.). (1996). The age of transition: Trajectory of the world-system, 1945-2025. London: Zed.

Hugill, P. J. (1999). Global communications since 1844: Geopolitics and technology. Baltimore, MD: Johns Hopkins University Press.

Innis, H. A. (1950). Empire and communications. Oxford: Clarendon Press.

Johnson, C. (2005). The sorrows of empire: Militarism, secrecy, and the end of the republic (the American Empire Project). New York: Metropolitan.

Kahin, B., \& Foray, D. (Eds.). (2006). Advancing knowledge and the knowledge economy. Cambridge, MA: MIT Press.

Keohane, R. O. (1989). International institutions and state power. Boulder, CO: Westview.

Kitchin, R., Lauriault, T. P., \& McArdle, G. (Eds.). (2017). Data and the city. New York: Routledge.

Latham, R., \& Sassen, S. (Eds.). (2005). Digital formations: IT new architectures in the global realm. Princeton, NJ: Princeton University Press.

Lee, W. S., \& Sohn, S. Y. (2018). Effects of standardization on the evolution of information and communications technology. Technological Forecasting and Social Change, 132, 308-317. 
Lessig, L. (1999). Code and other laws of cyberspace. New York: Basic.

Lipsey, R. G. (1999). Sources of continued long-run economic dynamism in the 21 st century. In The future of the global economy: Towards a long boom? (pp. 33-76). Paris: OECD.

Matzke, W.-E. (2013). Biotechnology, synthetic biology, and ICT define the emerging knowledge-based bio-economy. In Information and Communication Technologies in Education, Research, and Industrial Applications (pp. 1-19). Springer, Cham. https://doi.org/10.1007/978-

\section{3-319-03998-5_1}

McKelvey, M. D. (2000). Evolutionary innovations: The business of biotechnology. New York: Oxford University Press.

McNeill, J. R., \& McNeill, W. H. (2003). The Human Web: A Bird's-Eye View of World History. New York: W.W. Norton.

Mensch, G. (1979). Stalemate in technology: Innovations overcome the depression. Cambridge, MA: Ballinger.

Mitchell, K., \& Kallio, K. P. (2017). Spaces of the geosocial: Exploring transnational topologies. Geopolitics, 22(1), 1-14. https://doi.org/10.1080/14650045.2016.1226809

Modelski, G., \& Thompson, W. R. (1996). Leading sectors and world powers: The coevolution of global politics and economics. Columbia, SC: University of South Carolina Press.

Morris, I. (2010). Why the West Rules-for Now: The Patterns of History, and What They Reveal About the Future. New York: Macmillan.

Mueller, M. (2010). Networks and states: The global politics of Internet governance. Cambridge, MA: MIT Press. 
Nelson, R. R., Winter, S. G., \& Schuette, H. L. (1976). Technical change in an evolutionary model. The Quarterly Journal of Economics, 90(1), 90-118. https://doi.org/10.2307/1886088

Nye, J. S. (2004). Soft power: The means to success in world politics. New York: PublicAffairs.

Nye, J. S. (2014). The regime complex for managing global cyber activities (Report No. 1) (p. 20). Ontario: Global Commission of Internet Governance. Retrieved from http://dash.harvard.edu/handle/1/12308565

OECD. (2013). The internet economy on the rise: Progress since the Seoul declaration. Paris: OECD. https://doi.org/10.1787/9789264201545-en

Ouzounis, C. A., \& Valencia, A. (2003). Early bioinformatics: The birth of a discipline - a personal view. Bioinformatics, 19(17), 2176-2190.

https://doi.org/10.1093/bioinformatics/btg309

Perez, C. (2002). Technological revolutions and financial capital: The dynamics of bubbles and golden ages. Cheltenham, UK: Edward Elgar.

Perez-Iratxeta, C., Andrade-Navarro, M. A., \& Wren, J. D. (2007). Evolving research trends in bioinformatics. Briefings in Bioinformatics, 8(2), 88-95. https://doi.org/10.1093/bib/bbl035

Post, D. G. (1995). Anarchy state and the internet: An essay on law-making in cyberspace. Journal of Online Law, Article 3, 1995, art. 3(par.

Rapkin, D. P., \& Thompson, W. R. (2013). Transition scenarios: China and the United States in the twenty-first century. Chicago: University of Chicago Press.

Rasler, K. A., \& Thompson, W. R. (1994). The great powers and global struggle, 1490-1990. Lexington: University Press of Kentucky. 
Rennstich, J. K. (2002). The new economy, the leadership long cycle, and the nineteenth k-wave. Review of International Political Economy, 9(1), 150-182.

\section{https://doi.org/10.1080/09692290110101135}

Rennstich, J. K. (2004). The Phoenix-cycle: Global leadership transition in a long-wave perspective. In T. E. Reifer (Ed.), Hegemony, globalization and antisystemic movements (pp. 3553). Boulder, CO: Paradigm.

Rennstich, J. K. (2005a). Chaos or reorder? The future of hegemony in a world-system in upheaval. Journal of World-Systems Research, 11(2), 209-238.

https://doi.org/10.5195/jwsr.2005.390

Rennstich, J. K. (2005b). Three steps in the globalization of the international system: Global networks from 1000 BCE to 2053 CE. In B. K. Gills \& W. R. Thompson (Eds.), Globalization and Global History (pp. 203-231). London: Routledge.

Rennstich, J. K. (2008). The making of a digital world: The evolution of technological change and how it shaped our world. New York: Palgrave Macmillan.

https://doi.org/10.1057/9780230611061

Rosecrance, R. N. (1999). The rise of the virtual state: Wealth and power in the coming century. New York: Basic.

Rosenau, J. N., \& Singh, J. P. (Eds.). (2002). Information technologies and global politics: The changing scope of power and governance. Albany: State University of New York Press.

Sander, J. D., \& Joung, J. K. (2014). CRISPR-Cas systems for editing, regulating and targeting genomes. Nature Biotechnology, 32(4), 347-355. https://doi.org/10.1038/nbt.2842 
Sassen, S. (Ed.). (2002). Global networks, linked cities. New York: Routledge.

Sassen, S. (2006). Territory, authority, rights: From medieval to global assemblages. Princeton, NJ: Princeton University Press.

Sassen, S. (2013). When territory deborders territoriality. Territory, Politics, Governance, 1(1), 21-45. https://doi.org/10.1080/21622671.2013.769895

Scott, A. J., Agnew, J., Soja, E. W., \& Storper, M. (2001). Global City-Regions: An Overview. In A. J. Scott (Ed.), Global City-Regions : Trends, Theory, Policy: Trends, Theory, Policy (pp. 11-30). Oxford: Oxford University Press.

Shannon, C. E. (1948). A mathematical theory of communication. Bell System Technical Journal, 27(3), 379-423. https://doi.org/10.1002/j.1538-7305.1948.tb01338.x

Shy, O. (2001). The economics of network industries. Cambridge: Cambridge University Press.

Skocpol, T. (1977). Wallerstein's world capitalist system: A theoretical and historical critique. American Journal of Sociology, 82(5), 1075-1090.

Soetaert, W., \& Vandamme, E. J. (Eds.). (2010). Industrial biotechnology sustainable growth and economic success. Weinheim: Wiley-VCH.

Spar, D. L. (2001). Ruling the waves: Cycles of discovery, chaos, and wealth from compass to the internet. New York: Harcourt.

Standage, T. (1998). The Victorian internet: The remarkable story of the telegraph and the nineteenth century's on-line pioneers. New York: Walker.

Talalay, M., Farrands, C., \& Tooze, R. (Eds.). (1997). Technology, culture, and competitiveness: Change and the world political economy. New York: Routledge. 
Thompson, W. R. (Ed.). (1983). Contending approaches to world system analysis. Beverly Hills, CA: Sage.

Thompson, W. R. (1990). Long waves, technological innovation, and relative decline.

International Organization, 44(2), 201-233. https://doi.org/10.1017/S0020818300035256

Thompson, W. R. (2000). The emergence of a global political economy. London: Routledge.

Tinbergen, J. (1983). Kondratieff cycles and so-called long-waves: The early research. In C. Freeman (Ed.), Long waves in the world economy (pp. 18-31). London: Butterworths.

Townsend, A. M. (2001a). Network cities and the global structure of the internet. American Behavioral Scientist, 44(10), 1697-1716.

Townsend, A. M. (2001b). The Internet and the Rise of the New Network Cities, 1969-1999. Environment and Planning B: Planning and Design, 28(1), 39-58.

Tripathi, K. K. (2000). Bioinformatics: The foundation of present and future biotechnology. Current Science, 79(5), 570-575.

Wallerstein, I. M. (1974). The modern world-system: Capitalist agriculture and the origins of the European world-economy in the sixteenth century (Vol. 1). New York: Academic Press.

Wallerstein, I. M. (1980). The modern world-system: Mercantilism and the consolidation of the european world-economy, 1600-1750 (Vol. 2). New York: Academic Press.

Wallerstein, I. M. (1991). Geopolitics and geoculture: Essays on the changing world-system. Cambridge: Cambridge University Press. 
Wallerstein, I. M. (1993). World system versus world-systems: A critique. In A. G. Frank \& B. K. Gills (Eds.), The world system: Five hundred years or five thousand? (pp. 292-297). London: Routledge.

Wallerstein, I. M. (1999). The end of the world as we know it: Social science for the twenty-first century. Minneapolis: University of Minnesota Press.

Wallerstein, I. M. (2004). World-systems analysis: An introduction. Durham: Duke University Press.

Weiss, L. (Ed.). (2003). States in the global economy: Bringing domestic institutions back in. Cambridge: Cambridge University Press.

Wessner, C. W. (2001). Capitalizing on new needs and new opportunities: Government-industry partnerships in biotechnology and information technologies. Washington, DC: National Academies Press (US). Retrieved from https://www.ncbi.nlm.nih.gov/books/NBK208687/

Wilkinson, D. (2000). Civilizations, world systems, and hegemonies. In R. A. Denemark, J. Friedman, B. K. Gills, \& G. Modelski (Eds.), World system history: The social science of longterm change (pp. 54-84). New York: Routledge.

Wright, A. (2007). Glut: Mastering information through the ages. Washington, DC: Joseph Henry Press. 